\title{
Tensile Fracture Analysis of Key-Hole Notches by Means of the Strain Energy Density
}

\author{
A. R. Torabi, ${ }^{a}$ A. Campagnolo, ${ }^{\text {b }}$ and F. Berto ${ }^{\mathrm{b}, 1}$ \\ ${ }^{a}$ Fracture Research Laboratory, Faculty of New Science and Technologies, University of Tehran, \\ Tehran, Iran \\ ${ }^{\mathrm{b}}$ Department of Management and Engineering, University of Padova, Vicenza, Italy \\ ${ }^{1}$ berto@gest.unipd.it
}

УДК 539.4

\section{Анализ хрупкого разрушения по механизму отрыва в концентраторах напряжения типа "замочной скважины" с помощью критерия плотности энергии деформации}

\author{
А. Р. Тораби ${ }^{\mathrm{a}}$ А. Компаньоло ${ }^{\sigma}$, Ф. Бертоб \\ а Лаборатория исследования разрушения, Факультет инновационных технологий, Университет \\ г. Тегеран, Иран \\ ${ }^{\sigma}$ Факультет менеджмента и инжиниринга, Университет г. Падуя, Виченца, Италия
}

Получены новые экспериментальные данные о хрупком разрушении по механизму отрыва $в$ концентраторах напряжения типа “замочной скважины” и проверена возможность их прогнозирования с помощью критерия плотности локальной энергии деформации. Выполнено 21 испьтание на разрушение образиов из полиметилметакрилата в виде модифицированных “бразильских дисков” с центральным вырезом гантелеобразной формы (типа замочной скважины) при комнатной температуре. Экспериментальные величины разрушающих нагрузок достаточно точно рассчитаны для различных значений радиусов “гантелей” согласно критерию плотности локальной энергии деформации, усредненному по некоторому контрольному объему, охватывающему вершину концентратора. Показано, что экспериментальные данные хорошо согласуются с расчетными.

Ключевые слова: критерий плотности энергии деформации, концентратор напряжений типа “замочной скважины”, образец типа "бразильского диска", хрупкое разрушение.

Introduction. Depending on the crack length emanating from a notch border, different repairing methods are utilized to remove or stop the crack. For very large cracks, the most common method is to drill a stop hole leading to surround the crack tip and prevent it from extension. For notched members damaged by small cracks emanating from the notch border, a common repairing method is to remove the cracks by drilling a hole with the radius actually equal to the crack length. For U-shaped notches damaged by cracks, a key-hole or a nipple-shaped notch can be obtained from such repairing method depending on the ratio U-notch tip radius/crack length. As seen in Fig. 1, key-hole and nipple-shaped notches are resulted for the ratios smaller and larger than one, respectively. Since the level of stress concentration around the notch depends seriously on the notch feature, the fracture toughness of repaired notches should be theoretically and/or experimentally evaluated. 


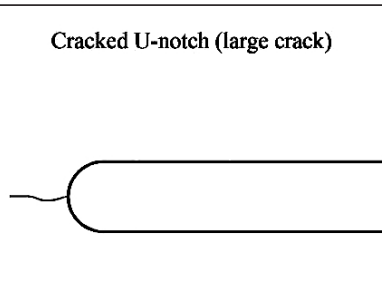

Cracked U-notch (small crack)

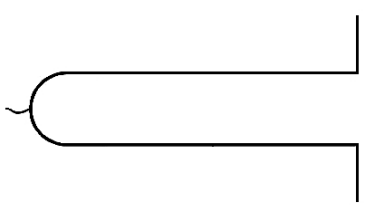

Crack removal

Key-hole notch

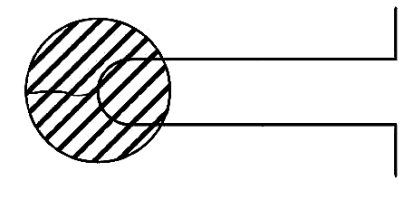

Crack removal

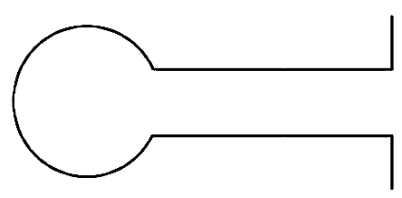

Nipple-shaped notch
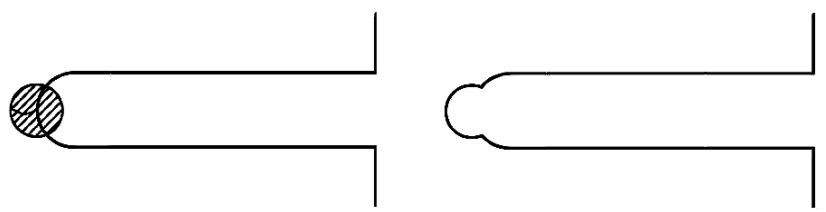

Fig. 1. Key-hole and nipple-shaped notches obtained from removing the cracks from U-notch border.

When one deals with brittle or quasi-brittle materials like graphite, ceramics, highstrength metals and alloys etc., much more attention is required to be paid to the design process since fracture in such materials happens suddenly with usually no precaution. If a brittle component or structure is weakened by notches, as man-made stress raisers, brittle fracture becomes much more serious because of the stress concentration. Thus, fracture toughness of notched brittle members should be carefully evaluated, either for original (e.g., U-shaped) or repaired (e.g., key-hole or nipple-shaped) notches.

Brittle fracture in notched components has been commonly studied in the past based on the linear elastic behavior of materials. Based on this particular behavior, a new field, namely the linear elastic notch fracture mechanics (LENFM), was born inside the fracture mechanics in which brittle fracture of notched members are analyzed by means of the well-known failure concepts of the fracture mechanics like the maximum tangential stress (MTS), the mean stress (MS), the cohesive zone crack model (CZM) and the strain energy density (SED), etc. Among various notch features, U and V-shaped notches have attracted great interest to be analyzed because of their extensive engineering applications (e.g., to provide a path of motion for reciprocating components, to fabricate bolts with $\mathrm{V}$ - and U-shaped threads, to provide grooves on shafts etc.). Moreover, in-plane loading conditions, namely, mode I, mode II and mixed mode I/II loadings have also been much more interested in comparison with the other types of loading such as mode III, again because of very common applications. A brief literature survey on the notch fracture mechanics is presented herein.

Gogotsi [1] investigated the fracture toughness of ceramics and ceramic-based composites considering different geometries of specimens under three and four point bending. Knesl [2] suggested a criterion for V-notch stability. Stress distribution near a large blunt V-shaped notch has been utilized by Nui et al. [3] in order to study the fracture toughness of brittle materials by means of the critical notch stress intensity factor. Seweryn [4] proposed a brittle fracture criterion for sharp V-notches and verified its validity by means of some experimental results. Considering plasticity at the notch tip vicinity, Strandberg [5] investigated successfully the fracture in V-notched specimens made of a type of soft annealed tool steel at $-50^{\circ} \mathrm{C}$. Gomez and Elices [6] proposed and utilized the CZM for estimating brittle fracture of sharp V-notches under opening mode. They verified the CZM predictions by means of mode I fracture test results obtained from V-notched samples made of PMMA [6]. In [7], a similar approach on the basis of the CZM has been utilized to predict mode I brittle fracture in U-notched specimens made of PMMA and 
subjected to three-point bending. Some recent investigations have been performed on notched members both theoretically and experimentally [8-14]. In the theoretical part, a successful use of the point-stress (PS) and the mean stress (MS) fracture criteria for predicting the mode I apparent notch fracture toughness (NFT) for V- and U-shaped notches is carried out. The theoretical NFTs have been verified by means of different brittle and quasi-brittle materials and various test specimens.

One of the most important theories in the context of brittle fracture of engineering components is certainly the strain energy density (SED) criterion. For cracked members, Sih [15] proposed the strain energy density factor (SEDF) by taking into account simultaneously both the strain energy density (SED) and the critical distance measured from the crack tip. According to the Sih criterion, brittle fracture takes place in a cracked brittle member when the SEDF attains its critical value [15]. The crack growth direction could also be determined by setting a minimum condition on the SEDF [15]. The Sih criterion is a point-wise criterion.

After that pioneering work [15], other researchers extended the SED concept to sharp and blunt notches (sharp and blunt V-notches, U-notches, etc.) by averaging SED over a specified control volume which embraces the notch edge with the aim to predict brittle fracture in notched components under different loading conditions [16-22]. The predictions of SED have been frequently verified by using the experimental results obtained from testing different specimens, materials and notches under various types of loading (mode I, mixed mode I/II etc.) [16-22]. Some recent works on the fracture analysis of blunt notches by means of SED are those published in [23-26]. The SED has been employed to assess the load-carrying capacity of U-notched Brazilian disk (UNBD) specimens made of polycrystalline graphite under pure mode I [23], pure mode II [24] and mixed mode I/II [25] loading conditions. It has been also analyzed mode I fracture of rounded-tip V-notches introduced in three different test samples made of graphite by means of SED [26]. Some recent studies deal with torsion [27] and compression loading [28] of graphite samples and the extension of the SED criterion to these cases.

Regarding brittle fracture of key-hole notches, only few papers have been published in the literature [29-31]. Kullmer and Richard [29] made satisfactorily use of a stress-based criterion to predict the fracture loads of the compact-tension-shear-notch (CTSN) specimens made of PMMA and subjected to mixed mode I/II loading. Lazzarin et al. [30] employed the local SED criterion to estimate the fracture loads of isostatic graphite plates weakened by horizontal (for mode I loading) and inclined (for mixed mode I/II loading) key-hole notches. The mode I test results reported in [30] have been re-analyzed by Torabi [31] using the two stress-based criteria, namely the PS and the MS criteria.

In the present work, tensile fracture of key-hole notches was studied both experimentally and theoretically. In the experimental part, 21 fracture tests were carried out on a new version of the well-known Brazilian disk specimen containing a central dumbbell-shaped slit with two key-ends (Key-BD) made of PMMA. The experimentally recorded fracture loads of the Key-BD specimens were theoretically estimated by means of the SED criterion for various notch radii. It was found that the SED criterion could predict the experimental results successfully with a scatter band of about $\pm 10 \%$.

1. Experiments. New fracture tests were conducted at room temperature on key-hole notched specimens made of PMMA. Details of the experiments are presented in this section.

1.1. Material. The most common material utilized in brittle fracture experiments is certainly the plexiglass or polymethyl-methacrylate (PMMA). Most of PMMAs exhibit quasi-brittle behavior at room temperature and brittle behavior at low temperatures (usually below $-60^{\circ} \mathrm{C}$ ). The PMMA utilized in the present experiments was the same is used in [32-34]. The mechanical properties of this material at room temperature are presented in Table 1 [32-34]. 
Tensile Fracture Analysis of Key-Hole Notches ...

$\mathrm{T}$ a b 1 e 1

Properties of the Tested PMMA at Room Temperature [32-34]

\begin{tabular}{|c|c|}
\hline Material property & Value \\
\hline Elastic modulus $E, \mathrm{GPa}$ & 2.96 \\
\hline Poisson's ratio $v$ & 0.38 \\
\hline Ultimate tensile strength $\sigma_{t}, \mathrm{MPa}$ & 70.5 \\
\hline Plane-strain fracture toughness $K_{\mathrm{I} c}, \mathrm{MPa} \sqrt{\mathrm{m}}$ & 1.96 \\
\hline
\end{tabular}

1.2. Specimen. The Brazilian disk specimen containing a central dumbbell-shaped slit with two key-ends (Key-BD specimen) was utilized to perform the mode I fracture experiments at room temperature (see Fig. 2). As seen in Fig. 2, the remote compressive load is applied to the specimen along the slit bisector line and hence, the key-ends experience pure opening mode (i.e., pure mode I loading).

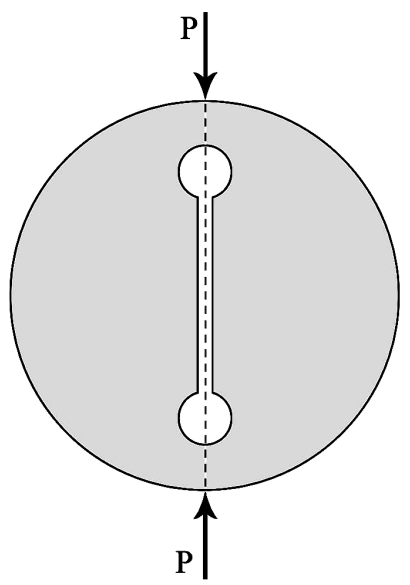

Fig. 2. The Key-BD specimen under mode I loading.

The disk diameter $(D)$ and the thickness $t$ were equal to $80 \mathrm{~mm}$ and $10 \mathrm{~mm}$, respectively. Two various slit lengths $(d)$ of 24 and $40 \mathrm{~mm}$ were considered in the tests. With these values of $d$, however, the values of the relative notch length ratio (RNL) $d / D$ were equal to 0.3 and 0.5 . To fabricate the Key-BD specimens, first, a PMMA plate of $10 \mathrm{~mm}$ in thickness was provided. Then, the precise sketch of each specimen was given to a high-precision 2-D CNC water jet cutting machine for fabrication. Finally, the cut surfaces were precisely polished by means of appropriate abrasive papers. Three notch radii of 1,2 , and $4 \mathrm{~mm}$ and four radii of $1,2,4$, and $6 \mathrm{~mm}$ were considered for the specimens with $d / D=0.3$ and 0.5 , respectively. The test speed was set to be equal to $0.3 \mathrm{~mm} / \mathrm{min}$ providing monotonic loading conditions. Each test was repeated three times with the aim to check the repeatability of the fracture tests. 21 tests were totally carried out in this investigation. A Key-BD specimen is represented in Fig. 3 during mode I fracture test. Also, Fig. 4 shows several Key-BD specimens after fracture.

The experimentally recorded fracture loads are presented in Table 2 for various notch radii and different values of the RNL ratio.

As seen in Fig. 5, the load-displacement plots obtained from the fracture tests were linear up to final fracture. Also, a sudden fall of the curve from the maximum load to zero proves that fracture occurred in a brittle matter. 
$\mathrm{T}$ a b 1 e 2

The Experimentally Recorded Fracture Loads of the Key-BD Specimens for Various Notch Radii and Different Values of the RNL Ratio

\begin{tabular}{|c|c|c|c|c|c||}
\hline $\begin{array}{c}\text { RNL } \\
(d / D)\end{array}$ & $\begin{array}{c}\rho, \\
\mathrm{mm}\end{array}$ & $\begin{array}{c}P_{1}, \\
\mathrm{~N}\end{array}$ & $\begin{array}{c}P_{2}, \\
\mathrm{~N}\end{array}$ & $\begin{array}{c}P_{3}, \\
\mathrm{~N}\end{array}$ & $\begin{array}{c}\langle P\rangle, \\
\mathrm{N}\end{array}$ \\
\hline 0.3 & 1 & 9391 & 9080 & 9302 & 9258 \\
\hline 0.3 & 2 & 8664 & 9361 & 9691 & 9239 \\
\hline 0.3 & 4 & 10891 & 10635 & 10768 & 10765 \\
\hline 0.5 & 1 & 6928 & 6859 & 6748 & 6845 \\
\hline 0.5 & 2 & 7015 & 6991 & 7040 & 7015 \\
\hline 0.5 & 4 & 6889 & 5992 & 6441 & 6441 \\
\hline 0.5 & 6 & 7173 & 6608 & 5957 & 6579 \\
\hline
\end{tabular}

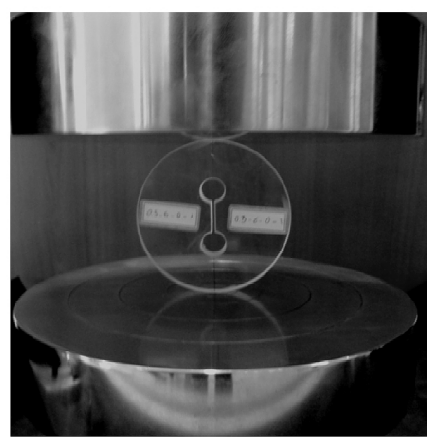

Fig. 3

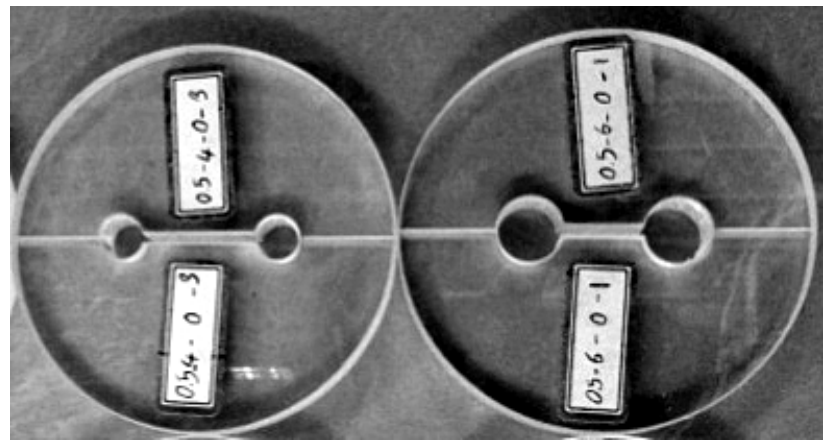

Fig. 4

Fig. 3. A Key-BD specimen during fracture test.

Fig. 4. Key-BD specimens after fracture.

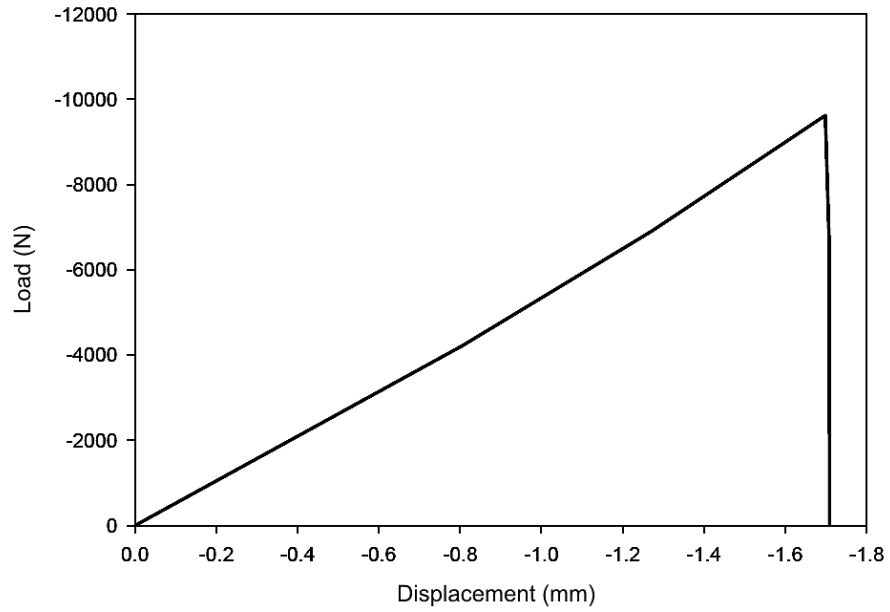

Fig. 5. A load-displacement plot for a Key-BD PMMA specimen.

In the forthcoming sections, the experimental fracture loads are theoretically predicted by means of the local SED criterion. 
2. Fracture Criterion Based on the Strain Energy Density Averaged Over a Control Volume. In order to estimate the fracture load of notched PMMA components, designers need a suitable fracture criterion based on the mechanical behavior of material around the notch tip. A strain-energy-density based criterion is described in this section, by which the fracture loads obtained from the experiments can be estimated with a reasonable accuracy.

As described in the introduction, dealing with cracked components, the strain energy density factor $S$ was defined first by Sih [15] as the product of the strain energy density by a critical distance from the point of singularity. Failure was thought of as controlled by a critical value $S_{c}$, whereas the direction of crack propagation was determined by imposing a minimum condition on $S$. Furthermore, this theory was used to study three problems of structural failure, namely the problem of slow stable growth of an inclined crack in a plate subjected to uniaxial tension, the problem of fracture instability of a plate with a central crack and two notches, and the problem of unstable crack growth in a circular disc subjected to two equal and opposite forces. The results of stress analysis were combined with the strain energy density theory to obtain the whole history of crack growth from initiation to instability. A length parameter was introduced to define the fracture instability of a mechanical system. Fracture trajectories were obtained for fast unstable crack propagation. The study of crack initiation and propagation is still an active research topic as demonstrated by some recent papers in the field [35-39]. This is particularly true when complex loading modes are taken into account [40-42].

Different from the Sih criterion, which is a point-wise one, the averaged strain energy density criterion (SED) as presented in [16-18], states that brittle failure occurs when the mean value of the strain energy density over a given control volume is equal to a critical value $W_{c}$. This critical value varies from material to material but it does not depend on the notch geometry and sharpness. The control volume, reminiscent of Neuber's concept of elementary structural volume [43], is thought of as dependent on the ultimate tensile strength and the fracture toughness $K_{\mathrm{I} c}$, in the case of brittle or quasi-brittle materials subjected to static loads.

Such a method was formalized and applied first to sharp (zero radius), V-notches under mode I and mixed I/II loading [16] and later extended to blunt U- and V-notches [17]. Some recent developments and applications are summarized in [44-46] with some considerations of the three-dimensional effects [47-50].

When dealing with cracks, the critical volume is a circle of radius $R_{c}$ centered at the tip [16]. Under plane strain conditions, the critical length, $R_{c}$, can be evaluated according to the following expression $[16,46]$ :

$$
R_{c}=\frac{(1+v)(5-8 v)}{4 \pi}\left(\frac{K_{\mathrm{I} c}}{\sigma_{\mathrm{t}}}\right),
$$

where $K_{\mathrm{I} c}$ is the fracture toughness, $v$ is Poisson's ratio, and $\sigma_{t}$ is the ultimate tensile strength of a plain specimen that obeys a linear elastic behavior.

For a key-hole, the volume assumes the crescent shape shown in Fig. 6 and defined in [28], where $R_{c}$ is the depth measured along the notch bisector line. The outer radius of the crescent shape is equal to $R_{c}+\rho / 2$ (Fig. 6).

Under mixed mode loading, the critical volume is no longer centered on the notch tip, but rather on the point where the principal stress reaches its maximum value along the edge of the notch. It was assumed that the crescent shape volume rotates rigidly under mixed mode, with no change in shape and size. This is the governing idea of the 'equivalent local mode I' approach, as proposed and applied to U- and V-notches [18, 19, $46]$. 


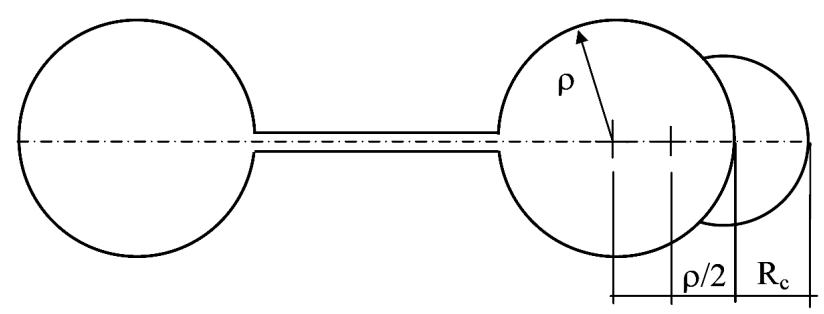

Fig. 6. Control volume under mixed mode loading for key-hole notched specimens.

Avoiding any simplified assumption, the SED values can be directly derived from finite element (FE) models. The advantage of the direct evaluation of the SED from a FE model is that the value of this parameter is mesh-independent as described in [50]. A very coarse mesh can be adopted for the SED evaluation contrary to the mesh required to evaluate the notch stress intensity factors or other stress-based parameters. An example is shown in Figure 7 comparing a typical fine mesh (Fig. 7a) with a coarse one (Fig. 7b) as employed in the present analyses.

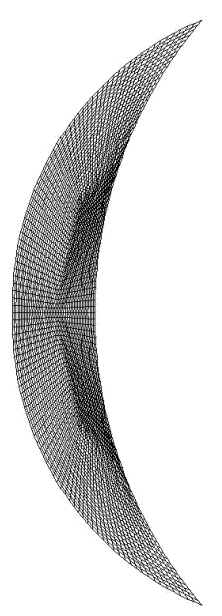

a

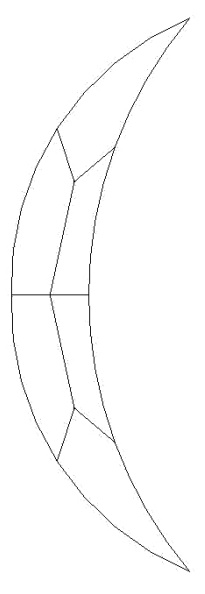

b

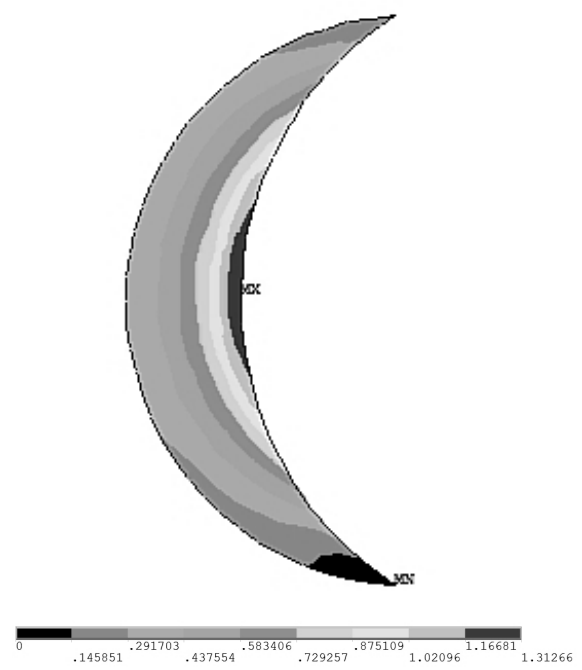

c

Fig. 7. Typical mesh used to evaluate the SED: (a) fine mesh; (b) coarse mesh; (c) SED contour lines.

3. SED Approach in Fracture Analysis of the Tested PMMA Specimens. The fracture criterion described in the previous section is employed here to estimate the fracture loads obtained from the experiments conducted on the PMMA specimens weakened by key-hole notches. In order to determine the SED values, a finite element model of the specimen was generated. A typical mesh used in the numerical analyzes is shown in Fig. 7a and $7 \mathrm{~b}$ for all the shapes of the specimens considered in the present investigation. The averaged strain energy density criterion (SED) states that failure occurs when the mean value of the strain energy density over a control volume, $\bar{W}$, is equal to a critical value $W_{c}$, which depends on the material but not on the notch geometry [16]. This critical value can be determined from the ultimate tensile strength $\sigma_{t}$ according to the Beltrami expression:

$$
W_{c}=\frac{\sigma_{t}^{2}}{2 E}
$$


In parallel, the control volume definition via the control radius $R_{c}$ needs the knowledge of the fracture toughness $K_{\text {Ic }}$ and Poisson's ratio $v$ [see Eq. (1)]. The critical load that is sustainable by a notched component can be estimated by imposing $\bar{W}$ to be equal to the critical value $W_{c}$. This value is considered here constant under mode I, mode II and in-plane mixed-mode conditions. This assumption has been extensively verified for a number of different brittle and quasi-brittle materials [18, 46].

As mentioned earlier, the properties of the PMMA considered in the present investigation are: $\sigma_{t}=70.5 \mathrm{MPa}, K_{\mathrm{I} c}=1.96 \mathrm{MPa} \sqrt{\mathrm{m}}$, and Poisson's ratio $v=0.38$. As a result, the critical SED for the tested PMMA is $W_{c}=0.839 \mathrm{MJ} / \mathrm{m}^{3}$, whereas the radius of the control volume is $R_{c}=0.166 \mathrm{~mm}$ considering trial plane strain conditions.

The SED occurring inside the control volume embracing the edges of the notches has been calculated numerically by using the FE code ANSYS. For each geometry, a model was created defining the control volume where the strain energy density should be averaged (see Fig. 7c). All the analyses have been carried out by using eight-node elements under the hypothesis of plane-strain conditions. Only negligible differences (less than 1\%) occur by using fine or coarse meshes.

Table 3 summarizes the outlines of the experimental, numerical and theoretical findings for the tested PMMA specimens, analyzed here by means of SED. In particular, the table summarizes the experimental loads to failure $P$ for every notch radius $\rho$ compared with the theoretical values $P_{t h}$ based on the SED evaluation. The tables also give the SED value as obtained directly from the FE models of the PMMA specimens by applying the average experimental load $\langle P\rangle$ to the model.

T a b 1 e 3

Experimental Fracture Loads Compared with Theoretical Ones Evaluated by Means of SED

\begin{tabular}{|c|c|c|c|c|c|c|c|c|c|c||}
\hline $\begin{array}{c}\mathrm{RNL} \\
(d / D)\end{array}$ & $\begin{array}{c}\rho, \\
\mathrm{mm}\end{array}$ & $\begin{array}{c}\langle P\rangle, \\
\mathrm{N}\end{array}$ & $\begin{array}{c}\mathrm{SED}, \\
\mathrm{MJ} / \mathrm{m}^{3}\end{array}$ & $\begin{array}{c}P_{t h}, \\
\mathrm{~N}\end{array}$ & $\begin{array}{c}P_{1}, \\
\mathrm{~N}\end{array}$ & $\begin{array}{c}P_{2}, \\
\mathrm{~N}\end{array}$ & $\begin{array}{c}P_{3}, \\
\mathrm{~N}\end{array}$ & $\begin{array}{c}\Delta_{1}, \\
\%\end{array}$ & $\begin{array}{c}\Delta_{2}, \\
\%\end{array}$ & $\begin{array}{c}\Delta_{3}, \\
\%\end{array}$ \\
\hline 0.3 & 1 & 9258 & 0.873 & 9076 & 9391 & 9080 & 9302 & -3.5 & 0.0 & -2.5 \\
\hline 0.3 & 2 & 9239 & 0.718 & 9989 & 8664 & 9361 & 9691 & 13.3 & 6.3 & 3.0 \\
\hline 0.3 & 4 & 10765 & 0.842 & 10744 & 10891 & 10635 & 10768 & -1.4 & 1.0 & -0.2 \\
\hline 0.5 & 1 & 6845 & 1.055 & 6103 & 6928 & 6859 & 6748 & -13.5 & -12.4 & -10.6 \\
\hline 0.5 & 2 & 7015 & 0.895 & 6794 & 7015 & 6991 & 7040 & -3.3 & -2.9 & -3.6 \\
\hline 0.5 & 4 & 6441 & 0.660 & 7262 & 6889 & 5992 & 6441 & 5.1 & 17.5 & 11.3 \\
\hline 0.5 & 6 & 6579 & 0.709 & 7155 & 7173 & 6608 & 5957 & -0.3 & 7.6 & 16.7 \\
\hline \hline
\end{tabular}

Note. The SED in the table has been evaluated applying the numerical model $P=\langle P\rangle$.

The last columns of the tables report the relative deviations between experimental and theoretical loads. As widely discussed in $[18,46]$, acceptable engineering values range from 0.8 to 1.2. As visible from the table, this range is satisfied for all the summarized test data.

The results are given also in graphical form in Fig. 8 where the experimental values of the critical loads (open dots) have been compared with the theoretical predictions based on the constancy of the SED in the control volume (solid line). The plots are given for the notched PMMA specimens as a function of the notch tip radius $\rho$. The trend of the theoretically predicted loads is in a good agreement with the experimental ones. 


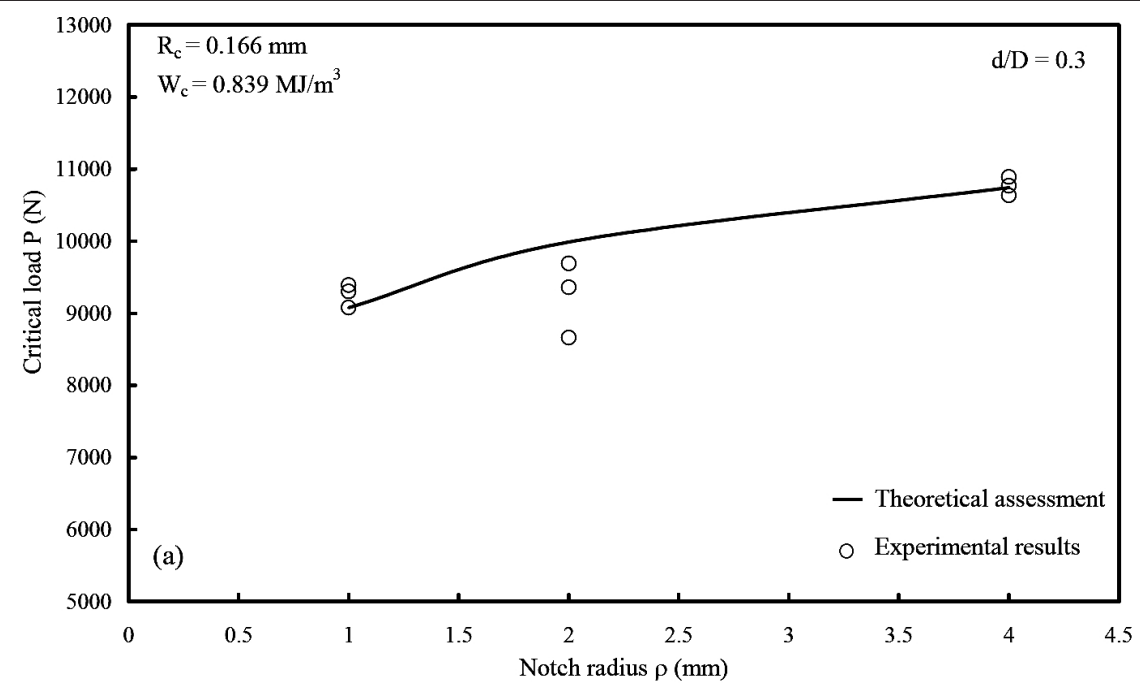

a

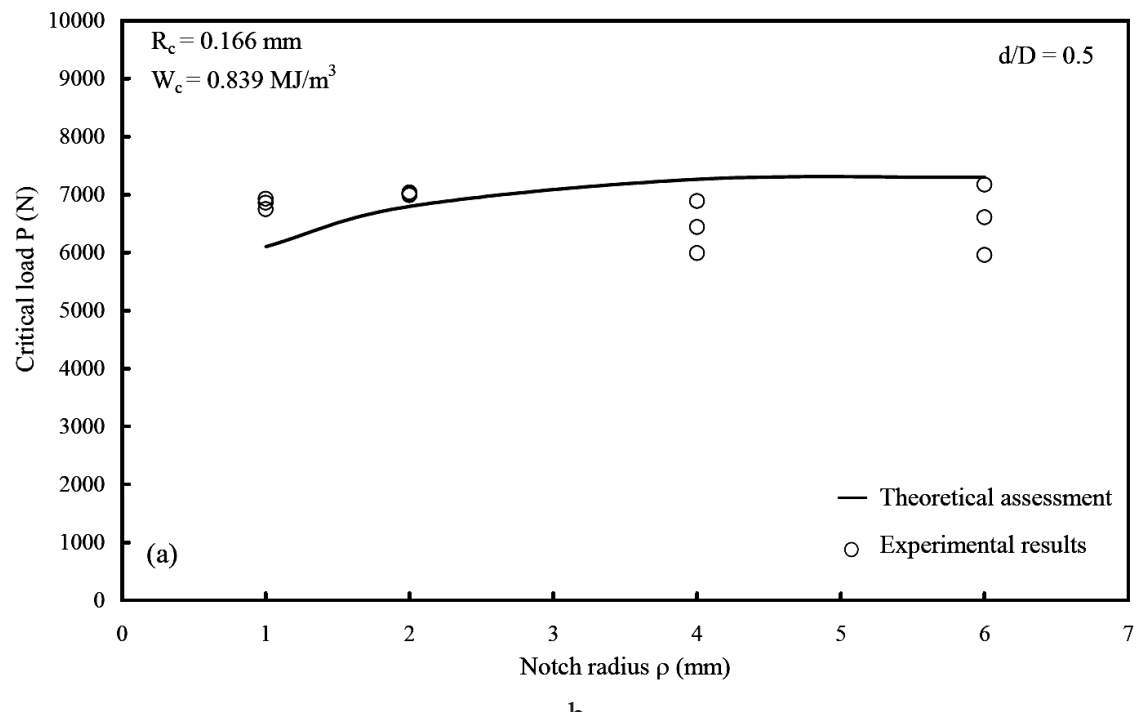

b

Fig. 8. Comparison between theoretical fracture loads obtained by SED and experimental data for $d / D=0.3$ (a) and $d / D=0.5($ b).

A synthesis in terms of the square root value of the local energy averaged over the control volume (of radius $R_{c}$ ), normalized with respect to the critical energy of the material as a function of the notch tip radius is shown in Fig. 9. The plotted parameter is proportional to the fracture load. The new data are plotted together independent of the notch geometries and specimens shape. The aim is to investigate the influence of the notch tip radius on the fracture assessment based on SED. From the figure, it is clear that the scatter of the data is very limited and almost independent of the notch radius. All the values fall inside a scatter ranging from 0.80 to 1.20 with the majority of the data inside 0.90 to 1.10. The synthesis confirms also the right choice of the control volume which seems to be suitable to characterize the material behavior under pure mode I loading. The scatter of the experimental data presented here is in a good agreement with the recent database in terms of SED reported in [16]. 


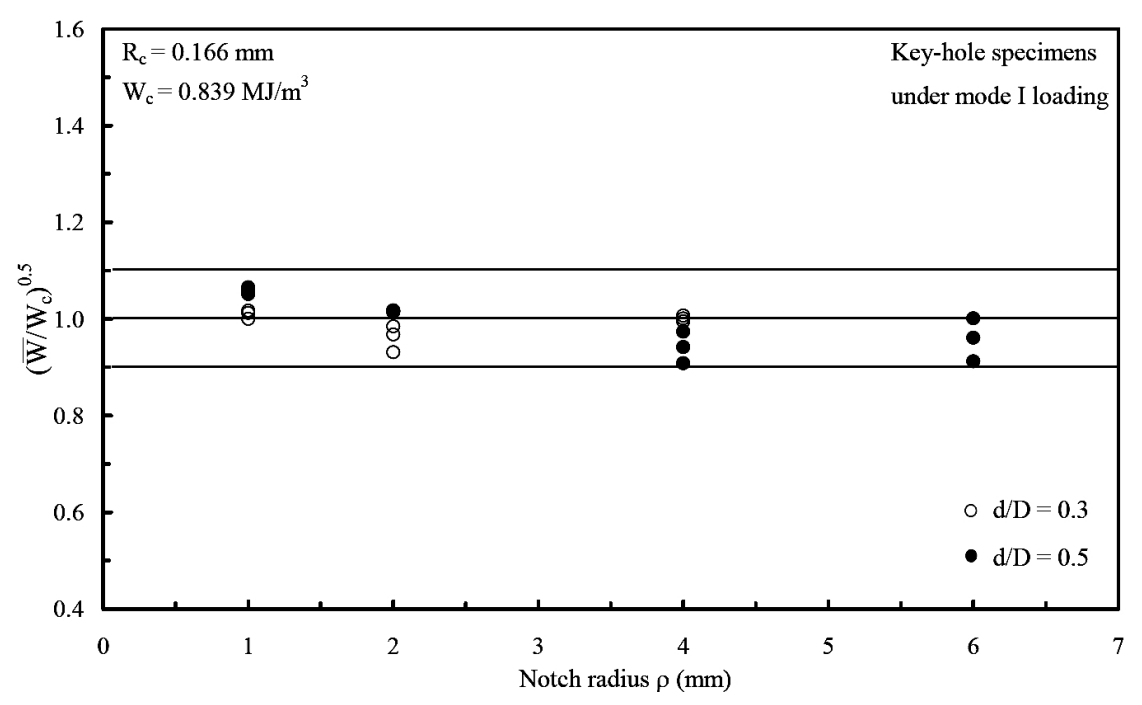

Fig. 9. Synthesis of brittle failure data from new fracture tests on PMMA specimens.

Conclusions. A new set of experimental results regarding tensile brittle fracture in key-hole notches is provided in the paper. The fracture loads of PMMA specimens weakened by key-hole notches were theoretically predicted by means of the wellestablished brittle fracture criterion, namely the strain energy density (SED) over a specified control volume, which embraces the notch edge. Different notched test specimens with two different $d / D$ ratios were considered in the predictions. All the theoretical results fall inside a scatter band of $\pm 20 \%$, the majority of which being inside a scatter band of $\pm 10 \%$ demonstrating the effectiveness and the repeatability of the SED criterion. The choice of the control volume size seems to be suitable for the considered material.

\section{Резюме}

Отримано нові експериментальні дані щодо крихкого руйнування за механізмом відриву в концентраторах напружень типу “замкової свердловини” і перевірено можливості їх прогнозування за допомогою критерію щільності локальної енергії деформації. Проведено 21 дослідження на руйнування зразків із поліметилметакрилату у вигляді модифікованих “бразильских дисків” із центральним вирізом у вигляді гантелі (типу замкової свердловини) за кімнатної температури. Експериментальні величини руйнівних напружень достатньо точно розраховані для різних значень радіусів “гантелей” згідно з критерієм щільності локальної енергії деформації, усередненим по деякому контрольному об’єму, що охоплює вершину концентратора. Показано, що експериментальні дані добре узгоджуються з розрахунковими.

1. G. A. Gogotsi, "Fracture toughness of ceramics and ceramic composites," Ceram. Int., 29, No. 7, 777-784 (2003).

2. Z. Knesl, “A criterion of V-notch stability,” Int. J. Fract., 48, No. 4, 79-83 (1991).

3. L. S. Nui, C. Chehimi, and G. Pluvinage, "Stress field near a large blunted tip V-notch and application of the concept of the critical notch stress intensity factor (NSIF) to the fracture toughness of very brittle materials," Eng. Fract. Mech., 49, No. 3, 325-335 (1994). 
4. A. Seweryn, "Brittle fracture criterion for structures with sharp notches," Eng. Fract. Mech., 47, No. 5, 673-681 (1994).

5. M. Strandberg, "Fracture at V-notches with contained plasticity," Eng. Fract. Mech., 69, No. 3, 403-415 (2002).

6. F. J. Gomez and M. Elices, "A fracture criterion for sharp V-notched samples," Int. J. Fract., 123, No. 3-4, 163-175 (2003).

7. F. J. Gomez, M. Elices, and A. Valiente, "Cracking in PMMA containing U-shaped notches," Fatigue Fract. Eng. Mater. Struct., 23, No. 9, 795-803 (2000).

8. M. R. Ayatollahi and A. R. Torabi, "Brittle fracture in rounded-tip V-shaped notches," Mater. Design, 31, No. 1, 60-67 (2010).

9. M. R. Ayatollahi and A. R. Torabi, "Tensile fracture in notched polycrystalline graphite specimens," Carbon, 48, No. 8, 2255-2265 (2010).

10. A. R. Torabi, "Fracture assessment of U-notched graphite plates under tension," Int. J. Fract., 181, No. 2, 285-292 (2013).

11. A. R. Torabi, M. Fakoor, and E. Pirhadi, "Tensile fracture in coarse-grained polycrystalline graphite weakened by a U-shaped notch," Eng. Fract. Mech., 111, 77-85 (2013).

12. A. R. Torabi, "Estimation of tensile load-bearing capacity of ductile metallic materials weakened by a V-notch: The equivalent material concept," Mater. Sci. Eng. A, 536, 249-255 (2012).

13. A. R. Torabi, "On the use of the equivalent material concept to predict tensile load-bearing capacity of ductile steel bolts containing V-shaped threads," Eng. Fract. Mech., 97, 136-147 (2013).

14. A. R. Torabi, "Ultimate bending strength evaluation of U-notched ductile steel samples under large-scale yielding condition," Int. J. Fract., 180, No. 2, 261-268 (2013).

15. G. C. Sih, "Strain-energy-density factor applied to mixed mode crack problems," Int. J. Fract., 10, No. 3, 305-321 (1974).

16. P. Lazzarin and R. Zambardi, "A finite-volume-energy based approach to predict the static and fatigue behavior of components with sharp V-shaped notches," Int. J. Fract., 112, No. 3, 275-298 (2001).

17. P. Lazzarin and F. Berto, "Some expressions for the strain energy in a finite volume surrounding the root of blunt V-notches," Int. J. Fract., 135, No. 1-4, 161-185 (2005).

18. F. Berto and P. Lazzarin, "A review of the volume-based strain energy density approach applied to V-notches and welded structures," Theor. Appl. Fract. Mech., 52, No. 3, 183-194 (2009).

19. P. Lazzarin, F. Berto, M. Elices, and J. Gomez, "Brittle failures from U- and V-notches in mode I and mixed, I + II, mode: A synthesis based on the strain energy density averaged on finite-size volumes," Fatigue Fract. Eng. Mater. Struct., 32, No. 8, 671-684 (2009).

20. M. R. Ayatollahi, F. Berto, and P. Lazzarin, "Mixed mode brittle fracture of sharp and blunt V-notches in polycrystalline graphite," Carbon, 49, No. 7, 2465-2474 (2011).

21. F. Berto, P. Lazzarin, and C. Marangon, "Brittle fracture of U-notched graphite plates under mixed mode loading," Mater. Design, 41, 421-432 (2012).

22. F. Berto and M. R. Ayatollahi, "Fracture assessment of Brazilian disc specimens weakened by blunt V-notches under mixed mode loading by means of local energy," Mater. Design, 32, No. 5, 2858-2869 (2011). 
23. A. R. Torabi and F. Berto, "Notch fracture toughness evaluation for a brittle graphite material," Mater. Perf. Charact., 3, No. 3, 1-16 (2014).

24. A. R. Torabi and F. Berto, "Strain energy density to assess mode II fracture in U-notched disk-type graphite plates," Int. J. Damage Mech., 23, No. 7, 917-930 (2014).

25. A. R. Torabi and F. Berto, "Mixed mode fracture assessment of U-notched graphite Brazilian disk specimens by means of the local energy," Struct. Eng. Mech., 50, No. 6, 723-740 (2014).

26. A. R. Torabi and F. Berto, "Fracture assessment of blunt V-notched graphite specimens by means of the strain energy density," Strength Mater., 45, No. 6, 635-647 (2013).

27. F. Berto, P. Lazzarin, and M. R. Ayatollahi, "Brittle fracture of sharp and blunt V-notches in isostatic graphite under torsion loading," Carbon, 50, No. 5, 1942-1952 (2012).

28. F. Berto, P. Lazzarin, and M. R. Ayatollahi, "Brittle fracture of sharp and blunt V-notches in isostatic graphite under pure compression loading," Carbon, 63, 101116 (2013).

29. G. Kullmer and H. A. Richard, "Influence of the root radius of crack-like notches on the fracture load of brittle components," Arch. Appl. Mech., 76, No. 11-12, 711-723 (2006).

30. P. Lazzarin, F. Berto, and M. R. Ayatollahi, "Brittle failure of inclined key-hole notches in isostatic graphite under in-plane mixed mode loading," Fatigue Fract. Eng. Mater. Struct., 36, No. 9, 942-955 (2013).

31. A. R. Torabi, "Closed-form expressions of mode I apparent notch fracture toughness for key-hole notches," J. Strain Anal. Eng. Design, 49, No. 8, 583-591 (2014).

32. M. R. Ayatollahi, A. R. Torabi, and P. Azizi, "Experimental and theoretical assessment of brittle fracture in engineering components containing a sharp V-notch," Exp. Mech., 51, No. 6, 919-932 (2010).

33. M. R. Ayatollahi and A. R. Torabi, "Determination of mode II fracture toughness for U-shaped notches using Brazilian disc specimen," Int. J. Solids Struct., 47, No. 3-4, 454-465 (2010).

34. M. R. Ayatollahi and A. R. Torabi, "Investigation of mixed mode brittle fracture in rounded-tip V-notched components," Eng. Fract. Mech., 77, No. 16, 3087-3104 (2010).

35. R. Brighenti and A. Carpinteri, "Buckling and fracture behaviour of cracked thin plates under shear loading," Mater. Design, 32, No. 3, 1347-1355 (2011).

36. A. Carpinteri, C. Ronchei, and S. Vantadori, "Stress intensity factors and fatigue growth of surface cracks in notched shells and round bars: Two decades of research work," Fatigue Fract. Eng. Mater. Struct., 36, No. 11, 1164-1177 (2013).

37. R. Brighenti and A. Carpinteri, "Surface cracks in fatigued structural components: A review," Fatigue Fract. Eng. Mater. Struct., 36, No. 12, 1209-1222 (2013).

38. R. Brighenti, A. Carpinteri, and A. Spagnoli, "Influence of material microvoids and heterogeneities on fatigue crack propagation," Acta Mech., 225, No. 11, 3123-3135, doi: 10.1007/s00707-014-1111-7 (2014).

39. R. Brighenti and A. Carpinteri, "Some considerations on failure of solids and liquids," Strength Mater., 42, No. 2, 154-166 (2010).

40. R. Brighenti, A. Carpinteri, and S. Vantadori, "Fatigue life assessment under a complex multiaxial load history: An approach based on damage mechanics," Fatigue Fract. Eng. Mater. Struct., 35, No. 2, 141-153 (2012). 
41. R. Brighenti and A. Carpinteri, "A notch multiaxial-fatigue approach based on damage mechanics," Int. J. Fatigue, 39, 122-133 (2012).

42. S. Vantadori, A. Carpinteri, and D. Scorza, "Simplified analysis of fracture behaviour of a Francis hydraulic turbine runner blade," Fatigue Fract. Eng. Mater. Struct., 36, No. 7, 679-688 (2013).

43. H. Neuber, Kerbspannungslehre, Springer-Verlag, Berlin (1958).

44. P. Lazzarin, A. Campagnolo, and F. Berto, "A comparison among some recent energy- and stress-based criteria for the fracture assessment of sharp V-notched components under Mode I loading," Theor. Appl. Fract. Mech., 71, 21-30, doi: 10.1016/j.tafmec.2014.03.001 (2014).

45. F. Berto, A. Campagnolo, M. Elices, and P. Lazzarin, "A synthesis of Polymethylmethacrylate data from U-notched specimens and V-notches with end holes by means of local energy," Mater. Design, 49, 826-833 (2013).

46. F. Berto and P. Lazzarin, "Recent developments in brittle and quasi-brittle failure assessment of engineering materials by means of local approaches," Mat. Sci. Eng. R., 75, No. 1, 1-48 (2014).

47. F. Berto and C. Marangon, "Three-dimensional effects in finite thickness plates weakened by rounded notches and holes under in-plane shear," Fatigue Fract. Eng. Mater. Struct., 36, No. 11, 1139-1152 (2013).

48. F. Berto, A. Kotousov, P. Lazzarin, and F. Pegorin, "On a coupled mode at sharp notches subjected to anti-plane loading," Eur. J. Mech. - A/Solids, 38, 70-78 (2013).

49. L. P. Pook, F. Berto, A. Campagnolo, and P. Lazzarin, "Coupled fracture mode of a cracked disc under anti-plane loading," Eng. Fract. Mech., 128, 22-36 (2014).

50. P. Lazzarin, F. Berto, and M. Zappalorto, "Rapid calculations of notch stress intensity factors based on averaged strain energy density from coarse meshes: Theoretical bases and applications," Int. J. Fatigue, 32, No. 10, 1559-1567 (2010).

Received 21. 09. 2015 